\title{
Crisis Narratives and the Tale of Our Anxieties
}

\author{
Hélène Ruiz Fabri
}

\begin{abstract}
Un sage oriental demandait toujours, dans ses prières, que la divinité voulût bien lui épargner de vivre une époque intéressante. Comme nous ne sommes pas sages, la divinité ne nous a pas épargnés et nous vivons une époque intéressante. En tout cas, elle n'admet pas que nous puissions nous désintéresser d'elle. Les écrivains d'aujourd'hui savent cela. S'ils parlent, les voilà critiques et attaques. Si, devenus modestes, ils se taisent, on ne leur parlera plus que de leur silence, pour le leur reprocher bruyamment. ${ }^{1}$
\end{abstract}

While I was struggling with the few lines below, Oscar Wilde's famous quote "the only thing worse than being talked about is not being talked about" came to my mind, and I briefly thought that the only thing worse than having nothing to say about crisis narratives was having to write about crisis narratives. After one pandemic year, and as a recently published comic showed accurately, I was a researcher looking for meaning in what she was doing. Indeed, was it possible to do something meaningful in research, except speaking of COVID-19? The big global pandemic crisis was probably covering millions of tiny individual crises like mine, each of us in our bubble. However, silence was not an option.

At first, the invitation to write about crisis narratives had thrilled me as it had immediately rung a bell. It made me feel young. Indeed, I had begun to struggle with the subject-matter of my doctoral thesis, customary international law, in a context where, if I were to believe the literature, the crisis was a core issue - the crisis of international law or the international legal system, crisis of customary international law, veering between instant and long term, wisdom and wildness (to borrow the words of René-Jean Dupuy opposing coutume sage et coutume sauvage). Said crisis played a significant part in the attraction

1 Albert Camus, Conférence d'Upsala, 14 décembre 1957, A. Camus, Essais, Bibliothèque de la Pléiade (Gallimard, 1965), p. 1079. 
to the topic as, where there is a crisis - or it is said so, there is certainly something new to say. Without that trigger, what could a young scholar bring to an eternal topic on which so much literature had already been published? The crisis had opened a window of opportunity, including to reflect on what allowed speaking of a crisis? About which crisis were people speaking?

Indeed, such vocabulary sounds quite dramatic and suggests something serious. However, it does not mean that there is consensus in all definitions that dictionaries provide for the term crisis. Some sources define a crisis as "a time of great danger, difficulty or confusion when problems must be solved, or important decisions must be made" (Oxford English Dictionary) or "a time when a problem, a bad situation or an illness is at its worst point" (Oxford Advanced American Dictionary). Other sources like the Trésor de la langue française propose a more sophisticated definition offering to stress the idea either of "sudden and intense manifestation of certain phenomena, marking a rupture", or of "a troubled situation, due to a loss of balance and the outcome of which is decisive for the individual or society, giving rise to fear or hope for a profound change" (translation of the author). The common trend is the drama reaching an apex; the differences are the connotations. A crisis is not necessarily dire and does not necessarily involve changes. One can wonder whether the more intense the drama, the more ineluctable the changes. Discourses may swing between the return to normal and prediction of a "new normal". Nevertheless, more than that, one can wonder about the state of mind of those using the qualification of crisis, either to study crises through the lens of international law or to study international law through the lens of crisis.

1/ To analyse crises through the lens of international law is incredibly banal. Each discipline, including international law, crosses fashions. Some words then become more common. Lately, international lawyers heard - and wrote a lot about empire and decolonisation. However, "crisis" is a word which seems to escape all fashions and never looks outdated, quite the opposite, always at hand to help approach and narrate a situation of broken balance. Whether this balance was satisfactory may be another issue. Notwithstanding, the corresponding underlying value judgement plays a role in the crisis narrative.

When I was drawn to the analysis of the concept of crisis, I could see crises everywhere. Indeed, the 198 os were a period of crisis. The new international economic order had aborted, just as the new international information order, the monetarist school was taking over Keynesianism, the contestation of the international legal order fizzled out, AIDs spread, famines tormented Ethiopia. Was it the 1970s which were a period of crisis in which the 1980s were receiving the effects and consequences? Oil shocks, the fall of the golden standard, a swarm of "nations prolétaires", in Franz Fanon's words, which were claiming 
their majority to put international law upside down. Nevertheless, weren't these the effects of the crisis/crises of the 196os? Decolonisation, the Vietnam war among many other national liberation wars, the South-West Africa case, the right of self-determination, Russian missiles in Cuba. Or maybe, these were the consequences of the 1950s? And so on back in time. The listed examples are necessarily subject to criticisms if one does not consider them as somehow randomly picked examples. They have in common to have at some point given way to an analysis, or a diagnosis, in terms of crisis. However, it shows how relativistic and flexible the term is, as a temporal and spatial perspective quickly shows.

Generally, crisis narratives are dated. What is seen as a crisis at some point may last in memories as a historical event but not as a "crisis" in most cases. That a situation or an event remains named a crisis does not even mean that it was more outstanding than others that lost such qualification through time, nor that it lasted longer. It might merely be that it has become part of its familiar name like "the Cuban Missile Crisis". In other words, the closer to an event or a situation, the greater the tendency to qualify it as a crisis, whereas such qualification might vanish through time. Crises are also located. The spatial scope can vary from global to local (which tells nothing about their intensity). Events or situations lived or seen as a crisis somewhere may not be seen as such elsewhere. There is no authority to tell us that the use of the word is more or less legitimate in one case than in another, even if everyone knows that it is part of a rhetoric which can be abused. Where is the term "crisis" located on the scale of our words? Does the question have a special bearing for lawyers, even more for international lawyers?

Having had to sit on a multidisciplinary body, I had the good fortune to meet with a physicist whose speciality was tribology. Simply put, it is the science of friction. A thousand images of various and varied frictions crossed my mind, making me laugh at first. Don't we spend a good part of our life scratching against one another, both literally and figuratively? I perceived the factual reality, but it took some explanation, and, as often for beginners, an excellent example to understand the scientific issue. Thus, I was told about the design of the tiles forming the envelope of a space shuttle. The latter rubs against the air when it takes off, then against something else (do not ask me) when it leaves the atmosphere. The nature and intensity of this friction - and the wear and tear it can generate - must be taken into account for the shuttle to resist and return. It was simple and obvious. It was also evident that it involved calculations that I could not understand, but the idea was there. Isn't law, or the discourse on law, itself a science and engineering of friction? Suffices to admit that relationships between physical and/or legal entities can be seen as frictions. Not any friction is unpleasant or damaging, but some may be. The rules surrounding our relationships may be aimed at preventing them from becoming unpleasant 
(prevention or lubrication) or helping to remedy the possible inconvenience (redress or redesign). What is a crisis from such a functional perspective? Is it one type of friction belonging as such to the usual business of law? Yes and no.

Indeed, there is a constant bias resulting from the fact that little is said in legal literature about what works well, which does not exclude vigilance or criticism, but because, like in newspapers, good news does not get much attention. Without a crisis, and the worry it causes, it is enough to let the law work as it is. Who cares about the rules of international air transport until a plane is shot down? In the absence of a crisis or one-off event, this remains an honourable and respected speciality but largely ignored. Perhaps if we admit that the jurist is to society what the physician is to the individual, does the tendency to be interested in pathologies more than good health make sense? It remains a bias nonetheless, and undoubtedly this bias affects academics more than practitioners. Perhaps crises help to enhance the usefulness of law - and lawyers - but also its limits?

Common wisdom wants crisis times to need rules more than ever to manage outstanding frictions that inevitably occur. Of course, there is more. "Crisis" is not only a convenient descriptor to convince of the seriousness of a situation or event without having to go into details. However, law has its language, while being itself a language. Jurists generally choose their words according to the legal consequences possibly attached to them (this is also why the word "crisis" may be avoided to prevent any idea of a pre-judgment. Thus, what is felt and/ or named a crisis in the field may become an "incident" when a case is brought before the International Court of Justice). Crisis is, on the legal scale of words, one of those which lead to at least two questions which are actually linked: the first and most immediate is that of the justification for exceptional measures; the second, which begins with the exception but extends beyond, is that of change.

These two questions have, of course, broader implications. They cover an assessment of the efficiency of the existing rules, provided one assumes law actually can play a role in solving or overcoming crises. In such a functionalist perspective, as much as rules are seen as tools to deal with crises, crisis narratives are tools to contextualise the rules. They are instrumental in explaining the existing rules' (in)adequacy and the eventual elaboration of new rules. One cannot ignore that significant changes often occur in the aftermath of crises, and it is often assumed or narrated that such changes would not have been possible without the preceding crisis. These changes are most of the time translated into legal rules which reflect the power balance then reached. That this balance is unstable is inevitable as society is a living body.

Nevertheless, law is conservative and does not move at the same pace as society. For example, it is often said that international humanitarian law is fighting the last war. More generally, law looks at life in a rear-view mirror. Not that it cannot have an anticipatory function, but the latter is closely linked to 
the past to which law answers and from which it was born. How do we tell this past, of which crisis narratives are part? Moreover, as mostly reflecting past times, law can play a role in triggering a crisis, when the gap between it and the facts is such that it becomes directly contested and the object of the crisis.

2/ Analysing international law through the lens of crisis leads to tackle the recurring issue of the crisis of international law itself. The literature is peppered with writings evoking the crisis of law, like the issue entitled "Crises dans le droit" (Crises within the law), ${ }^{2}$ published in 1986, in Droits, the Revue française de théorie juridique. Although not dedicated to international law, this publication pointed to issues which have also given rise to ample literature in international law and showed that crisis narratives as part of the discourse which supports what is said about the law, also speak about the narrators. This inevitably leads to wondering if the supposed crisis of the law is not also, or even above all, a crisis of the discourse on the law.

It all starts with expression of unease with the evolution of the law, what one might call a "technological crisis" (S. Rials). Law would not be anymore what it used to be. It would have become poorly manufactured, too quickly instrumentalised with an anarchic multiplication of rules. As if we had to answer every problem by enacting new rules because the existing ones would not be enough. It is indeed a multiplication of rules that has led to fragmentation, perceived by many as a pathology where others could see it as the opportunity for anti-hegemonic struggles, one of the dominant themes of the discourse on international law for more than two decades. From then on, the question was no longer only to assess whether the rules were "good"; it was also necessary to look at their articulation. Is this possible without a sufficiently informed overview which becomes beyond the reach of an ordinary international lawyer? Is this the legal translation of the rise of intersectionality?

Also, the said technological crisis affects the content as well as the container. Both have the disease of softness, also called relative normativity or managerialism. When it comes to content, the legal discourse is invaded by lacunae's assertion, while the absence of a specific written rule does not mean the absence of general principles. There are undoubtedly internal rationalisation efforts, such as those made by the International Law Commission. However, the use of "experts" no longer conceals the political agenda driving the endeavour. It reveals more than ever the instrumental vocation of law which, as a toolbox, could legitimise any purpose, but it also

2 Droits. Revue française de théorie juridique (Presses Universitaires de France, 1986), Issue 4. 
shows the increasing confrontation between the old and the new. It reflects the growing polarisation of doctrinal discourse and its welcome diversification which lets other voices be heard and opens the way to alternative crisis narratives.

As we can see, we have gradually slipped from the technological crisis to an epistemological, or even ontological, crisis. However, how do we tell the latter? Like any crisis narrative, it only makes sense if it reveals the battles of ideas and the power struggles that drive the crisis. What do we do with it? Finally, as Jan Klabbers has quite rightly said, is not there the risk that international lawyers end up speaking more of themselves than of international law? However, maybe the term of crisis is here too quickly used, as a contribution to a growing emphasis in vocabulary linked to the obligation to express oneself with slogans?

As it happens, one of the most popular these days is "Never let a good crisis go to waste". What remains at stake is our ability to talk about change and its feasibility and to use crisis narratives as a means of opening a critical discussion, not closing it. The difficulty is that our narratives are situated because we are situated. It is up to us to know how to deal with our eventual parochialism. Indeed, if international law is not international, crisis narratives can be as diverse as our visions of international law.

Concerning the relationship mentioned above between crisis and exception, the exception seems to have become the period's legal technique to address emerging concerns, not just in response to the pandemic but much more generally. The exception is schizophrenic. First of all, it claims to be provisional, but without giving up on becoming the rule. However, above all, it can contribute to putting at stake the base of values on which the provisionally waived rule relies. The emergency measures that the pandemic provokes and at the same time justifies bring back debates not only on democracy and the free will of citizens in a context of crisis (when and where they exist) but also on sovereignty, solidarity and borders. We cannot waive our values when narrating a crisis to speak of the law. The latter may be a paper tiger but can also be the watchdog of fundamental values, whether we speak of the existing law or the law we wish to happen. It is time to return to Camus' words, "Le monde serait toujours désespérant s'il n'y avait pas l'homme, mais il y a l'homme et ses passions, ses rêves et sa communauté." ${ }^{3}$

3 Albert Camus, Lecture: "La crise de l'homme" (McMillin Theater, Columbia University, New York, 28 March 1946) <https://perma.cc/JQF4-LG9X> accessed 21 March 2021. 